Purdue University Purdue e-Pubs

Libraries Research Publications

$10-1-2004$

\title{
Initial Visions of Paradise: Antebellum U.S. Government Documents on the South Pacific
}

Bert Chapman

Purdue University, chapmanb@purdue.edu

Follow this and additional works at: http://docs.lib.purdue.edu/lib_research

Chapman, Bert, "Initial Visions of Paradise: Antebellum U.S. Government Documents on the South Pacific" (2004). Libraries Research Publications. Paper 69.

http://docs.lib.purdue.edu/lib_research/69

This document has been made available through Purdue e-Pubs, a service of the Purdue University Libraries. Please contact epubs@purdue.edu for additional information. 


\title{
Initial Visions of Paradise: Antebellum U.S. Government Documents on the South Pacific
}

\author{
Bert Chapman
}

HSSE Library, Purdue University, 504 West State Street, West Lafayette, IN 47907-2058, USA

\begin{abstract}
During the first half of the 19th century, the United States grew from a nation confined to the Atlantic seaboard to a country on the verge of becoming a global power. One factor prompting this growth was the United States' growing intellectual, economic, and strategic interests in the Pacific Ocean. These growing interests were fueled by the material contained in governmental reports produced by entities such as the U.S. Exploring Expedition (1838-1842). This article examines U.S. government documents on the South Pacific ocean prior to the Civil War, how such documents contributed to the creation of the Smithsonian Institution, and how such documents enhanced American understanding of this region and helped contribute to expanded U.S. involvement in the South Pacific during the latter half of the 19th as well as the 20th century.
\end{abstract}

Keywords: U.S. government publications, South Pacific, U.S. Exploring Expedition, U.S. Navy history, Government-sponsored explorations

\section{Introduction}

At the dawn of a new millennium, it is easy for Americans to assume that the Pacific Ocean plays, and always has played, an important role in U.S. history and national economic and security policy. Such an assumption, however, is shortsighted and ignores the personalities and events that brought the Pacific Ocean to the important role it now plays in national life. This importance was influenced by the role played by U.S. Governmentsponsored expeditions and publications in expanding public knowledge of the South Pacific during the first half of the 19th century. Such governmental ventures also covered the North Pacific and would increase U.S. involvement in this vast ocean during the years after the

Bert Chapman is Government Publications Coordinator/Assistant Professor of Library Science at Purdue University Libraries. He received a B.A. in history and political science from Taylor University, an M.A. in history from the University of Toledo, and an M.S.L.S. from the University of Kentucky. His research interests include government publications on foreign policy and national security.

Tel.: 765-494-2837; fax: 765-494-9007, E-mail address: chapmanb@purdue.edu. 
Civil War, as well as into the 20th century, and continuing to the present.

Any discussion of the Pacific Ocean or any of its regions must begin by recognizing its immense scope and coverage. A recent work on its historical development offers the following appraisal:

The Pacific Basin covers one-third of the earth, an expanse of nearly 70 million square miles, and exceeds its combined land area. Its roughly triangular form extends nearly ten thousand land miles from the Bering Strait to the Antarctic Circle, and approximately the same distance along the equator from the Western Hemisphere to near the Asian mainland. Besides being the earth's largest body of water, it is also the deepest, ranging from an average depth of fourteen thousand feet to an extreme of over thirty-five thousand feet in the western Pacific, between Guam and Mindanao (Gibson, 1993, p. 13).

This immense natural description is matched by the diversity of the South Pacific's human cultures as is described in the following passage:

\begin{abstract}
The rimland and islands of the Pacific Basin have been the habitat of a mélange of peoples.... In Tierra del Fuego, are people whose ancestors in Pleistocene times migrated from Asia to the Western Hemisphere. The South American littoral features the traditionally fierce Araucanians, who pressed the coastal tributary peoples of the Andes-dwelling Incas.

... In Oceania the theme of diversity continues: blacks in Melanesia, Polynesian and Meso-Polynesian peoples in the Central and Southern Pacific and Micronesia, and contrasting peoples on the southwestern anchor of the Pacific Basin—aborigines in continental Australia, blacks in New Guinea, and Maori-Polynesians in New Zealand (Gibson, 1993, pp. 25-26).
\end{abstract}

\title{
2. Nineteenth century U.S. government-sponsored exploration
}

During the first half of the 19th century, U.S. territorial Expansion, through acquisitions such as the Louisiana and Gadsden Purchases, Guadalupe-Hidalgo Treaty, and agreements with Great Britain, increased the physical dimensions of the United States to continental proportions. The need for federal policymakers to understand the U.S. far-flung dominion led to governmental sponsorship of exploring expeditions such as Lewis and Clark's through what would become the Plains States and the Pacific Northwest, Stephen Long's and John Fremont's Rocky Mountain Surveys, the Pacific Railroad Survey, and other ventures (Haase, 1899, pp. 3-90; Goetzmann, 1959, 1966, 1986).

These explorations produced significant volumes of governmental reports that would expand national knowledge of recently incorporated territories. Besides providing cartographic data to increase geographic knowledge of these regions, these expeditions also produced detailed ethnographic documentation on indigenous inhabitants, increased scientific understanding through the collection of botanical and zoological specimens and climatic data, and heightened visual understanding of these regions through the drawings and paintings of expedition artists (Lewis \& Clark, 1806, pp. 705-743; Report of the Exploring Expedition to the Rocky Mountains, 1845, pp. 3-693; Reports of Explorations and Surveys to Ascertain the Most Practicable, 1855, pp. 3-651; Seavey, 1990, pp. 121-142; The U.S. Naval Astronomical Exploration to the Southern Hemisphere During the Years, 1855; Weiss, 1999, pp. 297-313). 


\section{The South Pacific Ocean as an emerging U.S. frontier}

Although these 19th century expedition reports produced an exponential surge in knowledge of the North American continent, they did not satisfy the desires of Americans and their government to increase national knowledge of the world during this period. By the 1820s, the U.S. government and individual Americans were developing increasingly international outlooks in their pursuit of economic wealth and national power. This expanded international outlook would include the South Pacific as a targeted area for expanded U.S. interest.

An example of increased U.S. economic interests in this region resulted in a U.S. naval expedition in 1826 to negotiate agreements providing for the friendly treatment of American ships and traders with the Society Islands (Tahiti) and Hawaii (Bemis, 1936, p. 342; Bevans, 1971, pp. 861-863).

Another example of increased U.S. economic interest in this region was the completion of an 1833 commerce and navigation treaty with Chile that included the exchange of diplomatic personnel between the two countries (Treaty with Chile: Message from the President of the United States, 1834, pp. 1-13). This treaty with Chile was but one demonstration of increasing U.S. interest in the South Pacific, its natural resources, and people (Campbell, 1989; Denoon, 1997; Edmond, 1997; Nile \& Clerk, 1996).

A tangible demonstration of increasing U.S. economic interest in the Pacific Ocean was the steadily increasing value of U.S. exports to and imports from the South Pacific prior to the civil war. Between 1821 and 1860, the annual value of U.S. exports to the South Pacific increased from zero to eight million dollars, and the value of U.S. imports from this region during this same period increased from less than US\$500,000 per year to four million dollars (U.S. Census Bureau, pp. 904, 907).

U.S. business interests in the Pacific Ocean dated from the earliest years of the nation's history. Gaining access to the lucrative China trade was a particularly important goal of the United States and other international business interests, with the Pacific Ocean serving as the principal transit point for goods and services bound for China. American and foreign participants in the China trade, and other forms of international trade, also came to appreciate the cornucopian value and variety the South Pacific could provide in enhancing their trading interests, as the following description illustrates:

\footnotetext{
The quest mounted for new items to sell to the Chinese. European, African, and South and Southeast Asian commodities reached Canton in American ship bottoms to augment the young republic's developing yet still limited economy. Sandalwood,... (the prized sea slug delicacy, Holothuria), tortoise shell, pearls, and pearl shell came from the Polynesian and Melanesian archipelagoes, Australia, Fiji, and New Zealand; edible birds' nests arrived from Indonesia and the Western Carolines. Between 1810-1830, the Hawaiian sandalwood trade led to virtually uncontrolled cutting of the islands' biggest and most accessible trees, from whose fragrant wood Chinese craftsmen contrived ornamental boxes, chests, and furniture; and joss sticks were made to burn as incense in Buddhist ceremonies. Trade with the Pacific islands included the supplying of ships with fresh water, firewood, vegetables, fruits, coconuts, and assorted provisions such as lumber and hemp for repairing vessels and rigging (Aldrich, 1990, pp. 15-34, 105-138; Dudden, 1992, p. 9; Johnson, 1963, pp. 2-3).
}

Recognition of the South Pacific's growing importance to the U.S. had reached the highest governmental circles during the 1820s. The most visible manifestation of this 
awareness was President John Quincy Adams' call for a government-sponsored expedition to explore the Pacific Ocean, which he made during his annual message to Congress on December 6, 1825 (American State Papers No. 412, 1825, Vol. 5, pp. 763-765). Adams' request would initially fall on deaf ears. Subsequent years and events would ultimately see Adams' request for such an expedition granted, with key political impetus for such an expedition coming from his New England compatriots.

\section{Pressure from New England whaling interests}

In the early years of the 19th century, the South Pacific became a lucrative focal point for European whaling ships. Both French and British whalers were involved in attempts to exploit this market, with 72 British whalers being registered with this fishery between 1800 and 1809-returning an average of 1634 tons of sperm oil and 3300 tons of whale oil, with an average annual total value of US \$1,040,000 (Global Financial Data, Annual Exchange Rate File, 2003; Stackpole, 1972, p. 282).

This South Pacific whale market became increasingly important to United States whaling interests, particularly to those in New England. During the second and third decades of the 19th century, control of South Pacific whaling grounds shifted from England to the United States, with vessels from New England ports such as Nantucket and New Bedford, Massachusetts, playing a particularly important role in this transformation (Dodge, 1965, pp. 27-56; Gray, 1999, pp. 23-43; Stackpole, 1972, pp. 371-372).

This U.S. dominance of South Pacific whaling grounds was not easily achieved. Knowledge of ocean currents, weather, and island locations was limited. This limited knowledge often resulted in loss of life and cargo to whalers and their ships. Concern over this lack of knowledge of the South Pacific lead New England fishing interests and their host communities to petition Congress to authorize a governmental expedition to explore and map the South Pacific in order to enhance the safety of crews sailing there. An example of U.S. governmental concern about insufficient knowledge of this region is expressed in the following correspondence between Secretary of Navy Samuel Southard (1787-1842) and Senate Naval Affairs Committee Chair Robert Hayne (D-SC) (1791-1839) (Biographical Dictionary of the American Congress, 1997, p. 1187; Garraty \& Carnes, 1999, Vol. 20, p. 565) in January 1829:

\footnotetext{
Our best charts and geographical works are extremely defective as to that region of the globe. Very little is accurately known about it. Very few islands, compared with the whole number which exist there, appear upon the charts, and the locations of the few which do are in most instances incorrect. It is well understood, from the experience of those of our citizens who are engaged in whaling and other pursuits in the Pacific, that there are, probably in the southern portion of it, not less than two hundred islands, reefs and shoals, which do not appear upon any chart. The situation of these is not known to many, and perhaps with strict accuracy as to latitude and longitude, none. Hence, all our vessels which sail there sail in constant and imminent peril, and an immense destruction of lives and property is the consequence (Exploring Expedition to the Pacific Ocean and South Seas: Communicated to the Senate, 1829).
}

During the 1820s and 1830s, Congress received numerous petitions from New England and other east coast communities asking that the federal government authorize a South Pacific exploring expedition to enhance knowledge of this region for the benefit of U.S. 
sailors and ships. A March 17, 1828, petition from New Bedford, Massachusetts, stressed that existing navigational charts were dangerously inaccurate and outlined federal authorization and funding of an exploring expedition as the best remedy for this defect (Petition of Citizens of New Bedford, 1828). A similar petition from Philadelphia was sent to Congress in December 1834 (Explore Southern Hemisphere, 1934).

An 1835 Rhode Island petition stressed the human cost of insufficient knowledge of the South Pacific by referring to several ships that had been lost in those waters, including one whose crew of 24 was massacred by local inhabitants-leaving only one survivor (On the Expedience and Importance of Authorizing a Naval Expedition to Explore the Pacific Ocean and South Seas, 1835).

Explorer and writer Jeremiah N. Reynolds (1799?-1858) played a particularly prominent role in petitioning Congress to support a South Pacific exploring expedition (Garraty \& Carnes, 1999, Vol. 18, pp. 379-380). Reynolds worked tirelessly to cultivate congressional opinion in favor of authorizing an exploring expedition during the 1830s. He emphasized the economic benefits expanded knowledge of the South Pacific would bring the United States in an 1836 congressional document.

No part of the commerce of this country is more important than that which is carried on in the Pacific Ocean.... Not less than $\$ 12,000,000$ capital are invested in and actively employed by the whale branch of the fishery alone; and in the whole trade there is, directly and indirectly, involved not less than fifty to seventy millions of property. In like manner, from 170,000 to 200,000 tons of our shipping, and from 9000 to 12,000 of our seamen are employed, amounting to about one-tenth of the whole navigation of the Union. Its results are profitable. It is, to a great extent, not a mere, exchange of commodities, but the creation of wealth, by labor, from the ocean. The fisheries alone produce, at this time, an annual income of from five to six millions of dollars; and it is not possible to look at Nantucket, New Bedford, New London, Sag Harbor, and a large number of other districts upon our northern coasts, without the deep conviction that it is an employment alike beneficial to the moral, political and commercial interests of our fellow citizens (On the Expedience of Authorizing an Exploring Expedition, 1836).

This document also used vivid emotional rhetoric and imagery to buttress its case for authorizing an exploring expedition:

No part of our commerce is exposed to so much hazard and peril. That portion of the globe is less known, and the ocean more filled with dangers, than any other that our seamen visit. There are hundreds of islands, reefs, and shoals, unmarked upon any chart, and unknown to common navigators. Their location, situation, facilities for commerce, are yet to be explored and exhibited to the world. Many of those islands are inhabited by savages, who render access to them dangerous, and whom it is the duty of the government to conciliate. The loss of property and life in that region has been immense (American State Papers No. 578, 1835; American State Papers Naval Affairs No. 620, 1868, Vol. 26).

\section{Congress authorizes U.S. Exploring Expedition}

Although it would take nearly a decade, the petitioning of New England fishing interests and Reynolds' persistent lobbying would ultimately produce desired dividends. The Senate approved authorizing legislation for a U.S. Exploring Expedition on April 27, 1836, by a 37-5 margin (Naval Bill, 1836). House approval, after contentious debate, came in a 92-68 vote on May 9, 1836 (Naval Service Bill, 1836). 
The bill, containing US\$150,000 in appropriations for the exploring expedition, received President Andrew Jackson’s signature 5 days later (Public Law 24-24, 1836).

\section{Setting up the U.S. Exploring Expedition}

Progress in setting up the U.S. Exploring Expedition was slow. After various delays, leadership rejections, and resignations by initially chosen naval officers, expedition command was accepted by Lieutenant John Wilkes on March 20, 1838 (Bryan, 1940, p. 555). Wilkes (1798-1877) was a relatively junior officer whose initial involvement in the expedition consisted of traveling to England and France to procure supplies. Despite being a skilled surveyor and navigator, Wilkes' junior status in the naval officer corps antagonized many colleagues (Garraty \& Carnes, 1999, Vol. 23, pp. 394-396; Morgan, 1978).

Wilkes would play a vital and highly controversial role in leading the expedition and publishing its results. Later in his career, as commander of the U.S.S. San Jacinto, he would also gain Civil War notoriety for his 1861 seizure of confederate diplomats from the British steamer Trent in international waters while on a mission to gain European support for the confederacy (Garraty \& Carnes, 1999, Vol. 23, p. 395).

Principal expedition planners included President Martin Van Buren's Secretary of the Navy Mahlon Dickerson (1770-1853), Reynolds, and Commodore Thomas Ap Catesby Jones (1790-1858). Jones had initially been appointed expedition commander. However, political intrigues and personal rivalries between these men and Wilkes ultimately resulted in Jones' replacement (Garraty \& Carnes, 1999, Vol. 6, pp. 551-553 and Vol. 12, pp. 251252; Goetzmann, 1986, pp. 270-272).

Despite delays, Wilkes was able to assemble a crew of five ships led by the U.S.S. Vincennes (Dictionary of American Naval fighting ships, 1981). Other ships in this naval expedition included the Peacock, Porpoise, Flying Fish, and Sea Gull (Viola \& Margolies, 1985, p. 257). The crew consisted of a variety of antebellum America's scientific luminaries including Yale mineralogist James Dwight Dana, ethnologist Dr. Charles Pickering, philologist Horatio Hale, Philadelphia naturalist and artist Titian Ramsey Peale (17991885), artists Alfred Agate and Joseph Drayton, botanist William Rich, and conchologist John Couthouy (Borthwick, 1965, pp. 159-172; Bryan, 1940, p. 557; Garraty \& Carnes, 1999, Vol. 17, pp. 203-205; Goetzmann, 1986, p. 273; Narrative of the United States Exploring Expedition, 1845, pp. xxiii-lvi).

These ships, along with their 490-member crew and civilian passengers, departed Norfolk, Virginia, on August 18, 1838 (Jackson, 1985, p. 49). A week before their departure, Wilkes and the expedition received instructions from Secretary of the Navy James K. Paulding (1778-1860) (Garraty \& Carnes, 1999, Vol. 17, pp. 164-166) concerning expedition directions and objectives.

You will proceed to the Feejee Islands, which you will examine with particular attention, with the view to the selection of a safe harbour, easy of access, and in every respect adapted to the reception of vessels of the United States engaged in the whale fishery, and the general commerce of these seas; it being the intention of the government to keep one of the squadron of the Pacific cruising near these islands in the future (Narrative of the United States Exploring Expedition, 1845, p. xxvi). 
Paulding's instructions detailed the diverse places the expedition would visit. These locales included Rio de Janeiro; Tierra del Fuego; exploring Antarctica as far south as British explorer James Cook; Australia; the Society Islands (Tahiti); Sandwich Islands (Hawaii); America's northwest coast, including the Columbia River; San Francisco, finding safe routes to China, traversing the Sea of Japan, and visiting Singapore (Narrative of the United States Exploring Expedition, 1845, pp. xxv-xxvii).

Along with this exhaustive travel itinerary, Paulding set stringent standards for protecting expedition property:

In the prosecution of these long and devious voyages, you will necessarily be placed in situations which cannot be anticipated, and in which, your own judgement and discretion, at others, necessity, must be your guide. Among savage nations, unacquainted with, or possessing but vague ideas of the rights of property, the most common cause of collision with civilized visitors, is the offence and punishment of theft. You will therefore adopt every possible precaution against this practice, and in the recovery of stolen property, as well as in punishing the offender, use all due moderation and forbearance (Narrative of the United States Exploring Expedition, 1845, p. xxviii).

Expedition instructions also included a prohibition against trade, except for essential supplies or souvenirs, and the following admonition about relationships with individuals or nations the expedition would encounter:

You will neither interfere, nor permit any wanton interference with the customs, habits, manners, or prejudices, of the natives of such countries or islands as you may visit; nor take part in their disputes, except as a mediator; nor commit any act of hostility, unless in self-defence, or to protect or secure the property of those under your command, of whom circumstances may have placed within reach of your protection (Narrative of the United States Exploring Expedition, 1845, pp. xxv-xxviii).

This conciliatory and diplomatic stance was further strengthened by the following passage which, although partially reflective of 19th century attitudes toward nonwestern cultures, still sought to emphasize the importance of the U.S. cultivating and maintaining good relations with the South Pacific residents.

\footnotetext{
Much of the character of our future intercourse with the natives of the lands you may visit, will depend upon the impressions made on their minds by their first intercourse with your vessels. It is the nature of the savage, long to remember benefits, and never to forget injuries; and you will use your best endeavors wherever you may go, to leave behind a favourable impression of your country and countrymen. The Expedition is not for conquest, but discovery. Its objects are peaceful; they are to extend the empire of commerce and science; to diminish the hazards of the ocean, and point out to future navigators a course by which they may avoid dangers and find safety (Narrative of the United States Exploring Expedition, 1845, pp. xxviii-xxix).
}

Paulding's instructions also included recommendations to preserve natural history specimens found during the expedition. The instructions included the following directive which, while intended to insure the official authoritativeness of expedition reports as government publications, would ultimately produce a controversy that would limit public distribution of the expedition's findings.

You will prohibit all those under your command from furnishing any persons not belonging to the Expedition, with copies of any journal, charts, plan, memorandum, specimen, drawing, painting, or information of any kind, which has reference to the objects or proceedings of the Expedition. It being 
considered highly important that no journal of these voyages, either partial or complete, should be published, without the authority and under the supervision of the government of the United States, at whose expense this Expedition is undertaken, you will, before you reach the waters of the United States, require from every person under your command the surrender of all journals, memorandums, remarks, writings, drawings, sketches, and paintings, as well as specimens of every kind, collected or prepared during your absence from the United States (Narrative of the United States Exploring Expedition, 1845, p. xxx).

\section{Exploring expedition underway}

From Norfolk, the expedition embarked for Madeira and Cape Verde Islands, before heading southwest to Rio de Janeiro, circumnavigating Cape Horn, and entering the Pacific by traversing South America's west coast in 1839 (Haskell, 1942,p. 5; Stanton, 1975; Viola \& Margolies, 1985, pp. 257-265).

\section{Initial Antarctic exploration}

Following a rendezvous at Tierra del Fuego on January 20, 1839, where Vincennes and Relief were left, expedition ships Porpoise, Sea Gull, Peacock, and Flying Fish headed south toward Antarctica to gain expanded knowledge about the icy southern continent. A key objective of this excursion was Wilkes desire to approach the 71810 minutes latitude position that British explorer James Cook had reached during his 18th century Antarctic voyage (Stanton, 1975, p. 96). The U.S. expedition has managed to see enough of the Antarctic continent to justify further exploration but was forced to return to Tierra del Fuego due to inclement weather and the approaching southern winter (Stanton, 1975, pp. 98-104; Viola \& Margolies, 1985, p. 15).

\section{South American experiences}

Following the abortive Antarctic excursion, the expedition turned its attention, during the first half of 1839, to exploring South America's west coast, spending time in Chile and Peru. Given the mandate to acquire scientific information about the South Pacific, expedition personnel began writing reports on topics as diverse as climatology, anthropology, ornithology, and navigation.

An observation about Chile's climate noted that the temperature in Santiago (Chile's capital) ranged between 60F and 75F; that irrigation from mountain streams kept Chile from being arid and barren for two-thirds of the year; and that when rains occurred, they were extremely heavy and rivers became impassable. Additional comments on Chile described the abundance of fruits such as apples, pears, peaches, cherries, grapes, strawberries, oranges, and a variety of vegetables (Narrative of the United States Exploring Expedition, 1845, pp. 184, 203).

The Chilean chronicle described burgeoning Chilean trade by noting the number of merchant vessels at the port of Valparaiso. It also noted that England, the United States, France, and Germany were the leading exporters to Chile; copper, copper ore, bullion, and 
hides were Chile's primary exports; and Chile's mining district was in the northern part of the country while its agriculture was concentrated in the south. A report on Peruvian silver noted that facilities were primarily surface mines, the ore was of poor quality, and the mines were unprofitable (Narrative of the United States Exploring Expedition, 1845, pp. 201-203, 262).

\title{
10. Tahiti
}

Expedition personnel reached Tahiti during September 1839, spending nearly 3 weeks in this area. The expedition report provides the following description of its natural composition:

\begin{abstract}
The whole island is of volcanic formation, but there is no longer any active igneous action, nor is there any well-defined crater to be seen. Coral reefs, with occasional openings, are attached to the shores, and the larger island (Tahiti) has also a sea reef. Between the two reefs is an almost continuous channel for Boat navigation, and on the northern side they enclose many safe and commodious harbors for shipping. On this side also vessels may pass from harbour to harbour within the outer reef. This reef varies in breadth from a few yards to 50 , or even a 100 . The shore that adjoins the coral reef is formed of black volcanic sand, occasionally mixed with comminuted shells, which give it a grayish hue. Basaltic ridges reach the sea at intervals, and form projecting points of moderate elevation (Narrative of the United States Exploring Expedition, 1845, pp. 4-5; Viola \& Margolies, 1985, p. 259).
\end{abstract}

Such descriptions of island topography were crucial to providing ships and governmental policymakers with navigational and charting information, which were key reasons behind the formation of the U.S. Exploring Expedition. A centralized governmental office for obtaining oceanic hydrographic charts was only achieved in 1838 with creation of the Depot of Charts and Instruments within the Navy Department (Bertrand, 1967, p. 262). Such emphasis on navigational mapping would prove to be of continuing importance and controversy within the U.S. Government during the 19th century (Manning, 1988).

Expedition members' writings would also encompass descriptions of the South Pacific's flora and fauna, given the presence of naturalists such as Peale. The following passage from Peale's journal, while being a zoological description of avian activity on a South Pacific island, also depicts an appealing and romantic portrait of this region to American readers:

The quantities of birds found breeding in various closed situations was quite incredible and they were all so tame as to require us in many instances to push them off the nest in order to see their eggs. The most conspicuous was the Frigate (Tachypetes aquilus) with nests constructed of a few sticks only, covered many of the trees by their numbers. The hoarse croaking and screaming as we disturbed them was incessant (Poesch, 1961, p. 152).

Exploring expedition writings was not limited to descriptions of scientific or natural phenomena. The South Pacific's diverse human cultures also received significant documentation and analysis in expedition writings. Wilkes criticized missionaries who sought to impose Western standards of dress on Tahitians by saying that such action had created unemployment among female Tahitian dressmakers and that Western fashion was not suitable for the local climate or the overall appearance of individual Tahitians (Narrative of the United States Exploring Expedition, 1845, p. 15). 
Wilkes made the following observation about Tahitian morality in light of prevalent Western portrayals of Tahiti as being a source of sexual pleasure for visitors.

Tahiti, when first visited, was proverbial for its licentiousness, and it would be asking too much, to require that after so short an enjoyment of the means of instruction, and in the face of such obstacles, its inhabitants should have as a body become patterns of good morals. Licentiousness does still exist among them, but the foreign residents and visitors are in a greater degree the cause of its continuance, and an unbridled intercourse with them serves to perpetuate it. Severe laws have been enacted, but they cannot be put in force in cases where one of the parties is a foreigner. I see no reason, however, why this island should be pointed out as conspicuous for licentiousness. When compared with many parts of the world that arrogate a superior civilization, it appears almost in an advantageous light (Narrative of the United States Exploring Expedition, 1845, p. 12; Stanton, 1975, pp. 123-130).

\section{Samoa}

Following the Tahitian sojourn, the Exploring Expedition set sail for the Samoan island group. Arriving in October 1839, they remained there for a month (Viola \& Margolies, 1985, p. 259). The report described the Samoan climate as being more varied than Tahiti's, with a higher humidity, which encouraged a luxuriance of Samoan vegetation (Narrative of the United States Exploring Expedition, 1845, p. 118).

Expedition members paid particular attention to Samoan fishing practices due to the economic importance of fishing to the Samoans, as well as to Americans and other Westerners interested in exploring and exploiting the South Pacific's rich marine resources. The following narrative describes a Samoan fishing practice:

One of the modes in which fish are caught by the Samoans, was witnessed at Samatau. About a dozen canoes formed themselves into a ring around what appeared to be a dark circular spot in the water, about six feet in diameter, and which was moving along with a slow and unequal motion. This was the shoal of a small fish called lou, which is about two inches in length. The shoal thus being surrounded, the circle of canoes was gradually lessened, until the fish, finding themselves enclosed on all sides, ceased to move forward. At this moment, the head fisher, who was seen standing up in the canoe with a net in his hand, threw it dexterously over the shoal, upon which all the other men dove at once from their boats, and remained for several seconds under the water, where they secured the sides of the net. On reappearing, all regained their canoes except four, who remained to take charge of the net, which with its prize they conveyed to the chief (Narrative of the United States Exploring Expedition, 1845, p. 123).

Further descriptions of Samoan life described the role of tattooing as a form of male initiation, canoe construction procedures, and house construction. Particular detail was given in describing this last activity, stating that Samoan houses were oval, consisting of a center and two ends, and explaining the roles played by rafters and rods in roof construction (Narrative of the United States Exploring Expedition, 1845, pp. 141-143, 145-146).

\section{Australia}

Following a November 10, 1839, departure from Samoa, the expedition crossed the International Date Line before arriving in Sydney, Australia on November 29 (Viola \& 
Margolies, 1985, p. 260). The expedition's stay in this British colony would enable members to experience the interactions between the colony's indigenous aboriginal inhabitants and its Western colonizers, who had become residents in their own right a half century after the commencement of British colonization efforts in this island continent.

Sydney was described as being divided into eastern and western parts, with the eastern side filled with grog shops and brothels and the western side being characterized by good houses, markets, a post-office, banks, and other accoutrements of civilization (Narrative of the United States Exploring Expedition, 1845, pp. 162-163; Stanton, 1975, p. 145).

The expedition's Australian experiences were not limited to Sydney's vices and attractions. Time was taken during the Australian stopover to explore the countryside surrounding Sydney and evaluate its topography and agricultural potential, as this passage demonstrates:

\begin{abstract}
The aspect of the country around Sydney is sufficient to prove that New South Wales is very different, in its general features, from other parts of the globe. This is chiefly owning to two causes: the aridity of the climate, and the prevalence of sandstone rock. This rock may be readily examined at the Heads of Port Jackson, and on the shores of the many coves that surround this beautiful harbor. Its colour is pale yellow or drab, and it lies in beds nearly horizontal and of various thickness, whose upper surface, except where broken by ravines and water-courses, forms a table-land. The average elevation in the neighborhood of Sydney is from three hundred and fifty to four hundred feet. At this level, it extends in gentle undulations to a great distance inland.

This arid soil yields but a scanty growth of vegetable products, which, consisting of burnt pasture, and thinlyscattered trees and shrubbery, give to the whole region a look of desolation. The grass does not everywhere conceal the bare rock, and the thin soil supports only a few gum trees (Euclypti), and bushes. Throughout the wide plain there is little to relieve the eye, except here and there a small cultivated spot (Narrative of the United States Exploring Expedition, 1845, p. 167).
\end{abstract}

This picture of arid agrarian desolation, however, is contrasted a few pages later by praise for the diverse foliage of the Illawara district, which is about 60 miles south of Port Jackson along the Pacific coast. The other extremes of agrarian and climactic conditions in New South Wales are seen in the descriptions of the 1839 floods in Hawkesbury Valley, which deluged area communities, destroyed local crops, and killed 20,000 sheep (Narrative of the United States Exploring Expedition, 1845, pp. 171-172).

Expedition narratives also provide considerable detail on Australian aboriginal life. Notice is made of rapid aboriginal demographic decline from an estimated peak of 200,000 to $60,000-75,000$, with alcohol, Western introduced diseases, and periodic war being cited as the primary reasons for this decline. The following passage illustrates the expedition chronicler's assessment of factors believed to be primarily responsible for the aboriginal population's dismal condition:

The introduction of European arts has caused but little improvement, while the vices which accompany them have been the bane of the native population, which has thus acquired a fondness for ardent spirits and tobacco. The natives usually lead a wandering, vagabond life, hanging about the houses of the settlers where they are well-treated, and doing little jobs, for a slight recompense... (Narrative of the United States Exploring Expedition, 1845, p. 184). 


\title{
13. Second Antarctic sojourn
}

Rested and replenished during their 4 weeks in Australia, the expedition, consisting of the Vincennes, Porpoise, Peacock, and Flying Fish, left Sydney on December 26, 1839, for a second effort to explore Antarctica and gain further knowledge about its coastline (Viola \& Margolies, 1985, pp. 18, 259-260). Icebergs were sighted at 61 degrees south latitude on January 13, 1840 (Jackson, 1985, p. 56), and crewmembers saw Antarctic mountains around January 16-17, 1840, in an area now known as Mawson's Peninsula. Disaster nearly struck the expedition on January 24, however, when the Peacock's rudder struck drift ice. Through the skill of its captain, and good fortune, Peacock was able to collide with another ice formation and recoil out to the open sea where it returned to Sydney for repairs (Goetzmann, 1986, pp. 280-281; Viola \& Margolies, 1985, p. 260).

A vivid demonstration of the harrowing nature of this Antarctic sojourn for wooden ships in the era prior to metallic ship construction and icebreakers is provided by the following description from the expedition's report narrative:

\begin{abstract}
We were swiftly dashing on, for I felt it necessary to keep the ship under rapid way through the water, to enable her to steer and work quickly. Suddenly many voices cried out, 'Ice ahead!' then 'On the weather bow!' and again, 'On the lee bow and abeam!' All hope of escape seemed to vanish; return we could not, or large ice-islands had just been passed to leeward: so we dashed on, expecting every moment the crash. The ship, in an instant, from having her lee guns under water, rose upright; and so close were we to passing to leeward of one of these huge islands, that our trysails were almost thrown aback by the eddy wind. The helm was put up to pay the ship off, but the proximity of those under our lee bade me keep my course. All was now still except the distant roar of the wild storm, that was raging behind, before, and above us; the sea was in great agitation, and both officers and men were in the highest degree excited. The ship continued her way, and as we proceeded, a glimmering of hope, arose, for we accidentally had hit upon a clear passage between two huge ice-islands, which in fine weather we should not dared to have ventured through. The suspense endured while making our way between them was intense, but of short duration; and my spirits rose as I heard the whistling of the gale grow louder and louder before us, as we emerged from the passage. We had escaped an awful death, and were again tempest-tost (Narrative of the United States Exploring Expedition, 1845, pp. 314-315; Stanton, 1975, pp. 150-185).
\end{abstract}

The expedition's Antarctic explorations covered some 1500 miles, navigating from 160 degrees east longitude to 100 degrees east longitude and establishing that Antarctica was a continent. A combination of lengthening daylight hours and crew illness forced Wilkes to order the expedition to return to Sydney on February 21, 1840. Following the expedition, controversy erupted over the nature and extent of Wilkes' Antarctic discoveries and findings as opposed to the findings of a British Antarctic expedition commanded by Captain James Clark Ross (Bertrand, 1967, p. 268; Goetzmann, 1986, p. 281; Gurney, 2000, pp. 163-178, 238, 272-273; Jackson, 1985, p. 58; Miterling, 1959, pp. 154-168; Viola \& Margolies, 1985, 18-19, 217).

\section{New Zealand}

After arriving in Sydney for supply replenishment on March 11, 1840, the expedition, minus the Peacock, which was still undergoing repairs, left for New Zealand on March 19 and reached its anchorage there on March 30 (Viola \& Margolies, 1985, p. 260). During 
their weeklong stopover, expedition members became acquainted with the culture of New Zealand's indigenous Maori inhabitants. They became familiar with the role played by the custom of taboo when they inquired about purchasing a canoe prow.

This proposed transaction proved problematic because the prow was located in a storehouse to which native access was forbidden. This situation was complicated further by a prohibition against carrying this prow across water in a canoe, even if a purchase agreement could be negotiated successfully (Narrative of the United States Exploring Expedition, 1845, p. 384).

The expedition narrative found Maori housing construction to be of particular importance and of impressive quality, as is demonstrated in the following community description:

\begin{abstract}
Within the main enclosure are other enclosures, each containing five or six houses, with alleys of two feet wide, that traverse the town. Their houses are simply constructed: four corner-posts are driven into the ground, and left from two to five feet above the surface; in the centre line two or three strong posts are firmly set in the ground, to support the ridge-pole of the roof; on the posts is placed and lashed a horizontal beam for the rafters to rest upon, and smaller poles are lashed to the posts, at one foot apart, from the ground up; for these the roofing is worked: the material used in thatching is the rush (Typha latifolia), or our common cattail. The manner of making the roof is to tie the materials on the horizontal strips or poles, setting the larger ends on the ground, and driving them close against each other, generally with the fist, and so on until all is closed in, leaving doorways under the eaves, at the gable-ends, the rappooing is then cut square off at the upper horizontal beam or plate-piece, and the roof is put on, made of the same material, and generally thatched with it or fern. The roofs have usually but little pitch, which gives a squat look to the houses. Mats are generally hung up at the doorways, and some have doors made of pine; they are low, obliging one to drop or creep, in entering (Narrative of the United States Exploring Expedition, 1845, pp. 385).
\end{abstract}

\title{
15. Fiji
}

The Fiji Islands were visited by the expedition from May until August 1840; the visit here proved to be the most tumultuous of any interaction expedition members would have with South Pacific nations (Viola \& Margolies, 1985, pp. 260-262). During the course of their Fijian visit, expedition members gathered 750 plant specimens, 118 examples of new coral species, and over 1200 artifacts. They also surveyed the islands' shoals and reefs, charted over 100 islands, and negotiated trade treaties with island leaders (Jackson, 1985, p. 58; Stanton, 1975, pp. 186-204).

Highlights of the expedition's Fijian narrative included descriptions of local religious practices, including the belief that lighter colored Fijians received more clothing from their deities than darker colored Fijians when they were first created. Additional characteristics of Fijian religious theology included the story of a great flood, the presence of many deities, the belief that one of those deities blesses or condemns individual spirits immediately after death, and that a giant seeks to deter individual spirits desirous of reaching the previous deity's judgement seat (Narrative of the United States Exploring Expedition, 1845, pp. 8283).

Another important aspect of expedition narratives concerning Fiji deals with cannibalism. Crew members were initially skeptical about reports that the Fijians practiced cannibalism, but their doubts were dispelled when an individual Fijian boarded the Vincennes eating a human eye (Stanton, 1975, pp. 202-203). Further description of the practice of cannibalism is provided in the following passage, which also demonstrates that expedition members did 
not subscribe to the 'noble savage' ideal held by some Western visitors toward previously unknown peoples:

The eating of human flesh is not confined to cases of sacrifice for religious purpose, but is practiced from habit and taste. The existence of cannibalism, independent of superstitious notions, has been doubted by many. There can be no question that, although it may have originated as a sacred rite, it is continued in the Feejee Group for the mere pleasure of eating human flesh as food. Their fondness for it will be understood from the custom they have of sending portions of it to their friends at a distance, as an acceptable present, and the gift is eaten, even if decomposition have begun before it is received. So highly do they esteem this food, that the greatest praise they can bestow on a delicacy is to say that it is as tender as a dead man (Narrative of the United States Exploring Expedition, 1845, p. 101).

Until arriving in Fiji, the relationships among expedition members and indigenous South Pacific islanders had been relatively positive. Relationships between Fijians and Americans, however, encountered turbulence. In 1834, a local leader named Vendovi, who was the brother of a Fijian king, murdered ten American crewmembers. Vendovi was captured soon after the expedition's arrival in Fiji (Jackson, 1985, p. 59; Viola \& Margolies, 1985, p. 18).

Soon after Vendovi's capture, two expedition crewmembers on a surveying party were killed by the Fijians. One of the victims was Wilkes' nephew. Wilkes retaliated by having his ships shell the fortified town of Malolo, killing over 80 Fijians and compelling their surrender. Vendovi remained imprisoned aboard expedition ships for the remainder of the expedition (Narrative of the United States Exploring Expedition, 1845, pp. 263-316; Viola \& Margolies, 1985, p. 18).

\section{Troubled relationships with Wilkes}

A significant reason for the success achieved by expedition members must be credited to Wilkes' leadership and tenacity. However, this leadership had flaws that created acute tension between Wilkes and those serving under his command. Despite his skills as a hydrographer, descriptive writer, and military leader, Wilkes' human relations skills were nearly nonexistent. Accusing his officers of plotting against him, Wilkes was rewarded with court martial charges being filed against him following the expedition, to which he responded with vehemence. He was, in many respects, a martinet, and this was reflected in his relationships with expedition personnel during the voyage and afterwards, as well as in his postexpedition relationships with naval officers and congressional appropriators (Dudden, 1992, p. 16; Garraty \& Carnes, 1999, Vol. 23, p. 395; Goetzmann, 1986, p. 272; Stanton, 1975, pp. 93-94).

One of the best examples of hostility toward Wilkes by an expedition member comes from the correspondence of Lieutenant William Reynolds, who kept an onboard journal during the expedition. Referring to Wilkes as a "false and malignant villain," Reynolds asserted that his actions were assaults on officers' professional conduct, and that there were only three individuals in the expedition squadron who would voluntarily support Wilkes in his actions (Cleaver \& Stann, 1988, p. 116).

Reynolds gives further voice to his own personal displeasure with Wilkes' arbitrary rule and to similar sentiments held by other expedition members, as demonstrated by the following narrative: 
Every man does his duty, but he keeps aloof from Captain Wilkes as if he were an adder and never trusts himself with him save in an official manner; thus you may see that the state of things is terrible indeed. Imagine a family where all are at variance with the father and you will know our state. But our consolation is that there is but one voice and feeling among us; we have suffered together and together we have resisted. There are no dissensions among us and we have the happiness to know in our own heart that we did not cast the first stone; we bore with circumstances until forbearance ceased to be a virtue and then we should have been stones not to have made ourselves heard (Cleaver \& Stann, 1988, p. 117).

Reynolds himself would suffer Wilkes' wrath for cooperating with other officers to produce a more harmonious housing arrangement for expedition officers. This wrath would result in Reynolds' incarceration, as he dramatically describes:

\begin{abstract}
He suspended me from duty and confined me to my apartment below decks for 6 to 7 days in the heat of a sweltering clime, put me on Penitentiary limits for an offense which I have no knowledge of, as it his avowed creed to punish first and inquire afterwards. Six days I remained in durance vile and the confinement was irksome to me, as you may suppose. Take me from air and liberty and what else is there? I would have rotted there, ere I would have opened my lips to complain; but at length he saw fit to send for me to let me know the cause of my suspension. The charge he had to bring against me was false and scandalous in the extreme, without the least foundation. I defied him to prove it, for I was indignant that I should have been persecuted for malice alone.... I had been punished and he, reckless of truth or consequences, cared not how his conduct was viewed (Cleaver \& Stann, 1988, pp. 117-119).
\end{abstract}

Reynolds' criticisms of Wilkes can be viewed as the natural displeasure of an insubordinate officer at his punishment. They can also be viewed as expressions of real concern felt toward what can be regarded as the arbitrary behavior of a tyrannical and insecure commander. While the truth probably rests somewhere between these two extremes, it is clear that the morale of exploring expedition personnel was seriously weakened by Wilkes' brusque treatment of naval officers and civilian personnel during the expedition's 4 years (Erskine, 1985).

\title{
17. Hawaii
}

Leaving Fiji on August 11, 1840, the expedition headed northeast to the Sandwich Islands (Hawaii). The island of Kauai was sighted on September 20, Oahu was reached on September 23, and they anchored in Honolulu harbor on September 24. Honolulu would serve as a central Pacific base while some expedition ships explored North America's northwest coast, while other expedition ships and personnel remained on the Hawaiian Islands (Viola \& Margolies, 1985, p. 262).

Highlights of the expedition's Hawaiian sojourn included Dana's geological work on Hawaiian volcanoes, which included determining crater depth and lava flow direction, and a successful ascent to the summit of Mauna Loa, with the assistance of supply personnel provided by Hawaiian King Kamehameha III. A magnetic observatory was also established on Mauna Loa. Ruins from the expedition's Mauna Loa campsite are the expedition's only known physical artifacts in the Pacific (Bertrand, 1967, p. 269; Forbes, 1992, pp. 98, 112118, 126-127; Stanton, 1975, pp. 224-225; Viola \& Margolies, 1985, p. 20). 


\section{Expedition returns to the United States}

The expedition left Honolulu on April 5, 1841, to survey North America's northwest coast. This phase of the expedition was successful in its charting activities but suffered the loss of the Peacock on a sandbar at the mouth of the Columbia River during July 1841. Next, the expedition traveled to California where, in October 1841, the expedition surveyed the San Francisco area and the Sacramento River (Goetzmann, 1986, p. 285; Viola \& Margolies, 1985, pp. 262-263).

The expedition then journeyed across the Pacific toward Hawaii before embarking on a westward journey home. Departing Hawaii on November 27, 1841, and heading west, the expedition reached the Philippines in January 1842. It then proceeded southwest, reaching Singapore on February 19, 1842. It was here that the Flying Fish was sold at auction because it had sustained damage during the expeditions' lengthy travels (and because Wilkes determined that it was no longer seaworthy). This southwestern path continued as the expedition's remaining ships entered the Indian Ocean on March 6, prior to reaching Capetown on April 14. The expedition made a 2-day stopover at St. Helena Island during May 1842, before arriving home at Sandy Hook, New Jersey, on June 10, 1842 (Stanton, 1975, pp. 247-280; Viola \& Margolies, 1985, pp. 262-265).

\section{Reactions}

Reaction to the expedition's return from a voyage of 87,780 miles, at a cost of US\$928,183.62 (Haskell, 1942, pp. 5-6), was less than euphoric. The expedition's aftermath, and its attempts to publish the findings, proved more problematic than a visit to the South Pacific would seem to call for.

The first symbolic demonstration of trouble for the expedition was the death of Fijian fugitive Vendovi at a New York City hospital shortly after the expedition's return (Goetzmann, 1986, p. 286). Further trouble loomed as news of Wilkes' contentious relationship with expedition members came to light. The expedition had been authorized by a Democratic administration but upon their return confronted the Whig administration of President John Tyler to attempt to diminish Wilkes' accomplishments (Haskell, 1942,p.6; Stanton, 1975, p. 308).

Wilkes' many enemies in the naval officer corps used the written accounts of expedition members, such as William Reynolds, to court martial Wilkes on charges of oppression, cruelty, disobeying orders, administering illegal punishments, and violating terms of enlistment, among other charges. Wilkes responded with his own countercharges against his accusers. Most of the charges against Wilkes were dropped due to their vagueness, but he was found guilty in 17 instances of administering illegal punishments. His sentence was a public reprimand, which his naval opponents regarded as too lenient. The reprimand, however, did sully Wilkes' reputation and the reputation of the exploring expedition in the court of public opinion (Jackson, 1985, p. 60; Stanton, 1975, pp. 281-289; Leonhart in Viola \& Margolies, 1985, 196-197). 


\section{Report publication problems}

Following the expedition's return, a key issue was to ensure the compilation and publication of expedition findings. Congress had first called for printing and distributing report findings in an 1842 law. A sign of the political controversy engendered by Wilkes' stormy relationships, however, was reflected in this statute's limiting printing of this report to 100 copies, which stands in stark contrast to the 10,000 copy printing Congress authorized for John Fremont's expedition reports (Garraty \& Carnes, 1999, Vol. 23, p. 395; Public Law 27-88, 1842).

An 1844 appropriation allocated US $\$ 40,000$ to publish expedition reports (Public Law 28-65, 1844) and an 1845 congressional resolution gave the Secretary of State 58 of these 100 report copies for distribution to designated foreign governments (A Resolution for Distributing the Work on the Exploring Expedition, 1845). This initial appropriation would activate a governmental appropriation process that would last for 30 years and produce still further controversy that would limit public distribution of the valuable data gathered by expedition members (Haskell, 1942, pp. 10, 16).

The authorization to fund the publication of this report had to go through Congress' Joint Committee on the Library, chaired by Rep. Benjamin Tappan (D-OH) (Garraty \& Carnes, 1999, Vol. 21, pp. 312-314). Wilkes' relationship with this committee would become increasingly contentious as attempts to obtain funding for the report, and finish its publication, became increasingly protracted and difficult. In a January 28, 1845, letter to the committee, Wilkes asserted that the report's publications would contain 15 textual volumes and nine atlases, broken down into a five-volume narrative that he would write. The narrative would include a volume on philology by Hale; volumes on mineralogy, geology, and corals by Dana; compilations on ornithology and mammalia by Peale; works on conchology by Augustus Gould; and additional works on botany, ichthyology, hydrography, physics, meteorology, and magnetism, at an estimated total cost of US\$89,370 (Haskell, 1942, pp. 18, 127; Maps, plates, \& c-Exploring Expedition, 1845, pp. 7-9; Stanton, 1975, pp. 305-392).

By the following year, it became necessary for the committee to revise the estimated printing costs and the number of volumes upward. A June 1846 committee document predicted that the number of text volumes would rise to 18 , with the number of atlases increasing to 11 . Overall printing costs would rise to US\$100,000 (Report to Accompany S. 214, 1846, p. 8). This same committee document also noted that Wilkes' narrative volumes and selected volumes by other expedition authors had been published. It also mentioned that Philadelphia publishers Lea and Blanchard (Haskell, 1942, pp. 20-21; Report to Accompany S. 214, 1846, pp. 8-10) had printed some report volumes.

The saga of publishing this work would exasperate all participating parties for years to come. Wilkes would encounter delays from various report contributors, as well as from natural disasters such as fires in Philadelphia binderies that destroyed volumes ready for press. These delays would, in turn, seriously strain the patience of congressional appropriators to the point when, in March 1859, one congressional appropriator would compare publishing the expedition reports to the protracted litigation of Jarndyce versus Jarndyce in Dickens novel Bleak House, while another appropriator recommended throwing the report into the Potomac River (Congressional Globe, 1859, pp. 1616-1618; Haskell, 
1942, pp. 12-15).

Controversies such as Secretary of the Navy Paulding's directive restricting nongovernmental publication of expedition reports, personal and political contentiousness, and seemingly innumerable delays would all combine to limit publication of report findings and restrict their dissemination. The most vivid indicator of such restricted dissemination was reflected in expedition reports not being included in the congressional serial set and in the last congressional appropriation of US\$9000, in 1872, for the report. Publication of report volumes was suspended in 1874 at a total of 24 volumes; four of these volumes were never printed or published. An additional two volumes were published by the private sector (CIS Index to Executive Branch Documents, 1994, pp. 32-35; Haskell, 1942, pp. 16-19).

\section{Reaction to reports}

Initial report volumes, primarily Wilkes narratives, were published in 1845 to relatively positive reviews. The Edinburgh Review observed that report contents contained minimal romantic adventure and "picturesque description." Its assessment went on to mention that its findings would be most beneficial to readers interested in ethnography, geography, and nautical information. This periodical also credited Wilkes for the report's successful organization and compilation and described him as being a prudent and scientific voyager (Narrative of the United States' Exploring Expedition, 1846, pp. 431-432, 452).

In the North American Review was the comment that expedition reports represented a source of national pride while enhancing navigational security and expanding knowledge in the world's developed nations. Further praise for the report, tempered with criticism of Wilkes for seeking copyright of selected report contents, is also reflected in this appraisal:

The 'Narrative of the Exploring Expedition,' in its mechanical finish, surpasses, probably, any large work ever published in the United States. It is filled with steel engravings and woodcuts, executed in the most perfect style of art and doing great honor to the artists, while they illustrate beautifully and appropriately the course of the story. An atlas, very useful to the studious reader, accompanies the five volumes. Two editions have been published; one, a quarto, where a 'rivulet of text meanders through a meadow of margin,' is intended for presentation to foreign governments; the other, a large octavo, containing the same engravings, is entered for copyright by Captain Wilkes. Seeing, however, that he has been munificently rewarded by his country, he ought not to receive the profits of this edition. The journals of the cruise belong either to the government, or to the officers by whom they were kept; and in neither case, it seems to us, can the commander claim their exclusive use for his private gain (Haskell, 1942, p. 17; United States Exploring Expedition, 1845, pp. 54, 106; U.S. Exploring Expedition, 1845, pp. 59-66).

\section{Expedition findings form Smithsonian nucleus}

The expedition acquired over 160,000 artifacts during its travels. Responsibility for these collections was given to Wilkes on August 1, 1843, and they were placed in the National Patent Office (Goetzmann, 1986, p. 288; Leonhart, 1985, p. 197). Placing expedition artifacts in the Patent Office proved to be a temporary expedient given the limited space at this Facility, which the Commissioner of Patents pointed out in 1842 (Report From the Commissioner of Patents, 1842, p. 3).

This concern over limited Patent Office storage space for expedition artifacts was 
emphasized again in the Commissioner's 1843 annual report. Stressing that there was insufficient display space for expedition artifacts, the commissioner advocated that funds from James Smithson's financial bequest to the United States be used to provide a repository for expedition materials (Report of the Commissioner of Patents, 1844, pp. 2-3).

Smithson's legacy was acted on, 3 years after publication of the Patent Commissioner's report, with the 1846 enactment of legislation to establish a Smithsonian Institution for "the increase and diffusion of knowledge among men" (Smithsonian Institution, 1901, pp. 429434). Unfortunately, it would take more than a decade to integrate exploring expedition artifacts fully into the Smithsonian Institution's holdings. This was finally accomplished by congressional action on June 2, 1858, appropriating US\$1000 for the formal transfer of these materials and US\$4000 for their preservation (Public Law 35-35, 1858; Smithsonian Institution, 1859, p. 52; Stanton, 1975, pp. 349-363; Reingold and Rothenberg in Viola \& Margolies, 1985, pp. 243-253).

Transferring exploring expedition collections to the Smithsonian facilitated easier public display of these items and marked the first time the Smithsonian displayed natural history specimens. Besides prompting creation of a national museum, the exploring expedition also gave American science a national orientation, with the Smithsonian serving as a clearing house for federal dissemination of scientific information and data (Goetzmann, 1986, p. 288; Reingold and Rothenberg, 1985, p. 250).

\section{Exploring Expedition legacies}

The U.S. Exploring Expedition's accomplishments were numerous and of enduring significance despite the often tempestuous relationships between Wilkes, naval officers, and civilian scientific personnel. Advances in nautical surveying on the expedition, such as the creation of more than 200 nautical charts, contributed to the creation of the United States Naval Observatory and helped American shipmakers lessen their dependence on foreign cartography. Wilkes' charts of Tarawa, in the Gilbert Islands, were used by U.S. naval forces during World War II (Jackson, 1985, p. 62; Morison, 1951, pp. 76, 153-154; Stanton, 1975,p. 365).

The 160,000 artifacts brought back by expedition personnel included more than 4000 zoological specimens, nearly 2000 of which represented new species. Birds accounted for more than 1100 specimens and 500 species. Plant specimens exceeded 50,000, including 10,000 different species. Thousands of ethnographic artifacts were collected and deposited in the Smithsonian, making its holdings of Pacific island materials one of United States' most important and systematic. The deposit of geological and marine artifacts, such as gems, fossils, and corals, enriched this treasure trove of material further. Both botany and geology emerged as professional disciplines as a result of this expedition and subsequent government sponsorship of scientific research (Gibson, 1993, pp. 363-364; Jackson, 1985, p. 62; Viola \& Margolies, 1985, p. 22).

Dana's reports on geology and crustacea from the expedition are regarded as classics in those fields. They proved the correctness of Charles Darwin's theory that Pacific atolls were geological constructions surrounding mountains and volcanoes that sank into the sea. Dana's expedition work also determined the approximate ages of the volcanoes forming Pacific 
islands, such as the Hawaiian chain, while anticipating the emergence of plate tectonics and continental drift (Goetzmann, 1986, pp. 291-292).

Drayton's and Agate's illustrations represent another important expedition contribution. Such illustrations represent the expedition's tangible visual contribution to expanding knowledge about unfamiliar locales in an era preceding the advent of photography, television, satellites, and Internet multimedia capability. Agate and Drayton, along with other expedition members such as Wilkes and Peale, depicted the dangers of sea travel, the starkness of icy Antarctic terrain, diverse animal and plant life, and the exotic peoples of the South Pacific in a variety of settings as they carried out their unique cultural customs. A fairly recent scholarly appraisal of the expedition's artistic contributions maintains they rank in importance with 19th century American artists, such as George Catlin (Goetzmann, 1986, pp. 287-288; Viola \& Margolies, 1985, pp. 37-39, 42, 44-45, 51, 54-55, 60-61, 63-65).

Despite the natural and human relations challenges of a 4-year global cruise, and the difficulties it encountered in getting its reports published and disseminated to a wide audience, the U.S. Exploring Expedition's accomplishments were significant. They established the federal government as a key sponsor and publisher of American scientific research, despite significant political opposition, and contributed to U.S. emergence as an increasingly important contributor to international scientific research (Goetzmann, 1986, p. 297; Stanton, 1975, pp. 364-377).

\section{Conclusion}

The South Pacific has been, and remains, a source of fascination for many due to its natural beauty, physical remoteness and isolation, and the unique personalities of its diverse individuals, cultures, and nations. The U.S. interest in the South Pacific originates from the desire of New England whaling interests to have expanded knowledge of that area's geographic features in order to protect their cargoes, crews, and financial bottom lines from treacherous currents, sandbars, storms, and hostile island residents.

U.S. government resource investments and publications, such as those of the U.S. Exploring Expedition, played a significant role in promoting national scientific professionalization, expanding antebellum America's knowledge of the South Pacific, and influencing American commercial and governmental activities in that region. These publications, and their subsequent print and electronic successors, chronicle how the United States has shaped, and continues to be shaped by, the Pacific frontier (Gibson, 1993, p. 420).

Despite the delay caused by the Civil War, these early government publications should be credited with influencing the much stronger role the United States would play in the South Pacific after the Civil War and continuing into the 20th and 21st centuries. The strong U.S.747 role is reflected in the increasing number of government publications on the South Pacific that have appeared, and continue to appear, since the 1842 return of the U.S. Exploring Expedition. These materials are still available through the bookshelves, microform cabinets, and computerized resources of depository and other libraries and are ready to enhance understanding of this fascinating global region. 


\section{Acknowledgments}

The U.S. Exploring Expedition reports are accessible through the Smithsonian Institution Digital Libraries Web site at www.sil.si.edu/digitalcollections/usexex/. For further reference and historical context not published in this article, please see "Other Antebellum U.S. Government Pacific Exploring Efforts" on my Purdue Libraries professional homepage at www.lib.purdue.edu/hsse/facultyandstaff/bibliographers/b_chapman.html .

The author would like to thank his wife, Becky Chapman, a Purdue University graphic designer, for her assistance in preparing the map and pictures used in this article. For pictures from the U.S. Exploring Expedition, visit www.sil.si.edu/digitalcollections/usexex/ .

\section{References}

Aldrich, R. (1990). The French Presence in the South Pacific, 1842-1940 (pp. 15-34, 105-138). Honolulu: University of Hawaii Press.

Bemis, S. F. (1936). A diplomatic history of the United States (pp. 342). New York: Henry Holt and Company.

Bertrand, K. J. (1967). Geographical Exploration of the United States. In H. R. Friis (Ed.), The Pacific Basin: A history of its geographical exploration (pp. 262, 269). New York: American Geographical Society.

Bevans, C. I. (1971). Treaties and other international agreements of the United States of America, 1776-1949, Vol. 8. (pp. 861-863). (1971). Washington, DC: GPO.

Biographical dictionary of the American Congress, 1774-1996. (1997). (pp. 1187). Alexandria, VA: CQ Staff Directories, Inc.

Borthwick, D. E. (1965). Outfitting the United States Exploring Expedition: Lieutenant Charles Wilkes' European assignment, August-November 1836.

Bryan, G. S. (1940). The purpose, equipment and personnel of the Wilkes expedition. Proceedings of the American Philosophical Society, 82(5), 555.

Campbell, I. C. (1989). A history of the Pacific Islands. Berkeley: University of California Press

CIS Index to US Executive Branch Documents, 1789-1909: Guide to documents listed in checklist of U.S. Public Documents, 1789-1909, not printed in U.S. Serial Set, Part 5 Navy Department, Reference Bibliography (pp. 32-35). Bethesda, MD: Congressional Information Service, Inc.

Cleaver, A. H. \& Stann, E. J. (Eds.). (1988). Voyage to the Southern Cross: The letters of Lieutenant William Reynolds from the U.S. Exploring Expedition, 1838-1842 (pp. 116 -119). Annapolis: Naval Institute Press. Congressional Globe. (1859). 35th Cong., 2nd Sess., 1616-1618.

Denoon D., et al. (Eds.). (1997). The Cambridge history of the Pacific Islanders (pp. 116-119). Cambridge, UK:

Cambridge University Press.

Dictionary of American Naval Fighting Ships. (1981). Vol. 7. (pp. 525-527). (1981). Washington, DC: Naval Historical Center, Department of the Navy.

Dodge, E. S. (1965). New England and the South Seas (pp. 27 -56). Cambridge, MA: Harvard University.

Dudden, A. P. (1992). The American Pacific From the Old China Trade to the Present, Vol. 9 (p. 16). (1992). New York: Oxford University Press.

Edmond, R. (1997). Representing the South Pacific: Colonial discourse from Cook to Gauguin (pp. 16). Cambridge, UK: Cambridge University Press.

Erskine, C. (1985). Twenty years before the mast. Washington, DC: Smithsonian Institution Press.

Explore Southern Hemisphere: Memorial of citizens of Philadelphia, Pennsylvania, praying an appropriation of the national funds for the purpose of making discoveries, \& c in the South Seas, Pacific Ocean, \& c. (1934). House Document 48, 23rd Cong., 2nd Sess., 1-2.

Exploring Expedition to the Pacific Ocean and South Seas: Communicated to the Senate February 16, 1829. (1829). American State Papers Naval Affairs No. 387, 20th Cong., 2nd Sess., 25: 312.

Forbes, D. W. (1992). Encounters with paradise: Views of Hawaii and its people, 1778-1941, Vol. 98. (pp. 112118, 126-127). Honolulu: Honolulu Academy of Arts.

Garraty, J. A., \& Carnes, M. C. (Eds.). (1999). American National Biography (Vol. 6, pp. 551-553; Vol. 12, pp. 251-252; Vol. 14, pp. 743-744; Vol. 17, pp. 164-166, 203-205, 367-369; Vol. 18, pp. 379-380; Vol. 20, p. 
565; Vol. 21, pp. 312-314; Vol. 23, pp. 394-396). New York: Oxford University Press.

Gibson, A. R., with the assistance of Whitehead, J. S. (1993). Yankees in Paradise: The Pacific Basin Frontier (pp. 13, 25-26, 363-364, 420). Albuquerque: University of New Mexico Press.

Global Financial Data, Inc. Annual Exchange Rate File. Available: www.globalfindata.com/trial/AGBP.csv . Accessed May 20, 2003.

Goetzmann, W. H. (1959). Army Exploration and the American West, 1803-1863. New Haven: Yale University Press.

Goetzmann, W. H. (1966). Exploration and empire: The explorer and scientist in the winning of the American West. New York: Alfred A. Knopf.

Goetzmann, W. H. (1986). New lands, new men: Americans and the second great age of discovery (pp. 91-92, 270-273, 380-381, 287-288, 297). New York: Viking.

Gray, A. S. (1999). Trading contacts in the Bismarck Archipelago during the Whaling Era, 1799-1884. Journal of Pacific History, 34(1), 23-43.

Gurney, A. (2000). The Race to the White Continent: Voyages to the Antarctic (pp. 163-178, 232, 272-273). New York: W.W. Norton and Company.

Haase, A. R. (1899). Report of explorations printed in the documents of the United States government (pp. 3-90). Washington, DC: GPO.

Haskell, D. C. (1942). The United States Exploring Expedition 1838-1842 and its publications 1844-1874: A bibliography (pp. 5-6, 12-19). New York: Greenwood Press Publishers.

Jackson, D. J. (1985 November). Around the world in 1392 days with the Navy's Wilkes and his 'Scientifics.' Smithsonian (16), 49-56, 58, 60, 62.

Johnson, R. E. (1963). Thence round cape horn: The story of the United States naval forces on Pacific Station, 1818-1923 (pp. 2-3). Annapolis: Naval Institute Press.

Leonhart, J. (1985). Charles Wilkes: A biography. In H. Viola, \& C. Margolies (Ed.), Magnificent voyagers: The U.S. Exploring Expedition, 1838-1842 (pp. 196 -197). Washington, DC: Smithsonian Institution Press.

Lewis and Clark's expedition communicated to Congress, February 19, 1806. (1806). American State Papers: Indian Affairs, 1, 705-743.

Manning, T. G. (1988). U.S. Coast Survey vs. Naval Hydrographic Office: A 19th-century rivalry in science and politics. Tuscaloosa: University of Alabama Press.

Maps, plates, \& c-Exploring Expedition-To accompany Joint Resolution H.R. No. 74. (1845). House Report 160, 28th Cong., 2nd Sess., 7-9.

Miterling, P. I. (1959). America in the Antarctic to 1840 (pp. 154-158). Urbana: University of Illinois Press.

Morgan W. J., et al. (Eds.). (1959). Autobiography of Rear Admiral Charles Wilkes U.S. Navy 1798-1877. Washington, DC: Naval History Division, Department of the Navy.

Morison, S. E. (1951). History of United States Naval Operations in World War II volume VII: Aleutians, Gilberts, and Marshalls June 1942-April 1944, Vol. 76 (pp. 153-154). (1951). Boston: Little, Brown and Company.

Narrative of the United States Exploring Expedition during the years 1838, 1839, 1840, 1841, and 1842. (1845). (Vol. 1, pp. xxiii-lvi, 184, 201-203, 262; Vol. 2, pp. 4-5, 12, 15, 118, 123, 141-143, 145-146, 162- 63, 167, 171-172, 184, 314-315, 384-385; Vol. 3, pp. 82-83, 101, 263-316). Philadelphia: Lea and Blanchard.

Narrative of the United States' Exploring Expedition, during the Years 1838-1842; by Charles Wilkes, U.S.N. (1846). Edinburgh Review, 83 (168): 431-432, 452.

Naval Service Bill. (1836). Register of Debates in Congress, 24th Cong., 1st Sess., 12: 3553-3578.

Navy Bill. (1836). Register of debates in Congress, 24th Cong., 1st Sess., 12: 1297-1298.

Nile, R., \& Clerk, C. (1996). Cultural atlas of Australia, New Zealand, and the South Pacific. New York: Facts on File.

On the expedience and importance of authorizing a naval expedition to explore the Pacific Ocean and South Seas. (1835). American State Papers Naval Affairs No. 578, 23rd Cong., 2nd Sess., 26:708.

On the expedience of authorizing an exploring expedition, by vessels of the Navy to the Pacific Ocean, and South Seas. (1836). American State Papers Naval Affairs No. 620, 24th Cong., 1st Sess., 26: 867.

Petition of citizens of New Bedford praying that a naval expedition may be undertaken for the exploration of the North and South Pacific Ocean, and other seas, visited by whale ships and others. (1828). House Document 201, 20th Cong., 1st Sess., 3.

Poesch, J. (1961). Titian Ramsey Peale 1799-1885 and his journals of the Wilkes expedition (pp. 152). Philadelphia: American Philosophical Society.

Public Law 24-24. (1836). 5 United States Statutes at Large, 27-29. 
Public Law 27-88. (1842). 5 United States Statutes at Large, 534.

Public Law 28-65. (1844). 5 United States Statutes at Large, 691.

Public Law 35-35. (1858). 11 United States Statutes at Large, 301.

Reingold, N., \& Rothenberg, M. (1985). The Exploring Expedition and the Smithsonian Institution in Viola and Margolies. Magnificent voyagers (pp. 243 -253). Washington, DC: Smithsonian Institution.

Report of the Exploring Expedition to the Rocky Mountains in the year 1842 and to Oregon and North California in the years 1843-'44 by Brevet Captain J.C. Fremont. (1845). Senate Document 174, 28th Cong., 2nd Sess., 3-693.

Report from the commissioner of patents, showing the operation of the patent office during the year 1841 . (1842). Senate Document 169, 27th Cong., 2nd Sess., 3.

Report of the commissioner of patents, showing the operations of the patent office during the year 1843. (1844). Senate Document 150, 28th Cong., 1st Sess., 2-3.

Report to accompany S. 214. (1846). Senate Document 405, 29th Cong., 1st Sess., 8.

Reports of explorations and surveys to ascertain the most practicable and economical route for a railroad from the Mississippi River to the Pacific Ocean. (1855). House Executive Document 91, 33rd Cong., 2nd Sess., 3-651.

A Resolution for Distributing the Work on the Exploring Expedition. (1845). Resolution 28-5. 5 United States Statutes at Large, 797.

Seavey, C. A. (1990). Government graphics: The development of illustration in U.S. Federal Publications, 18171861. Government Publications Review, 17(2), 121-142.

Smithsonian Institution. (1859). Annual report of the Board of Regents of the Smithsonian Institution showing the operations, expenditures, and condition of the institution for the year 1858 (pp. 52). Washington, DC: James B. Steedman.

Smithsonian Institution. (1901). The Smithsonian Institution documents relative to its origin and history: 18351899 (pp. 1429 -1434). Washington, DC: GPO.

Stackpole, E. A. (1972). Whales and Destiny: The rivalry between America, France, and Britain for control of the Southern Whale Fishery, 1785-1825 (pp. 282). Amherst, MA: University of Massachusetts Press.

Stanton, W. (1975). The Great United States Exploring Expedition of 1838-1842 (pp. 93-94, 96, 98-104, 123130, 145, 150-204, 224-225, 247-289, 364-377). Berkeley: University of California Press.

Treaty with Chile: Message from the President of the United States transmitting copies of a Treaty of Peace, Amity, Commerce, and Navigation, between the United States and the Republic of Chile, March 15, 1834. (1834). House Document 418, 23rd Cong., 1st Sess., 1-13.

U.S. Exploring Expedition. (1845). Littell's Living Age, 5(48), 59-66.

The U.S. naval astronomical exploration to the Southern Hemisphere during the years 1849-50-51-52: Volume 1 Chile. (1855). House Executive Document 121, 33rd Cong., 1st Sess.

United States Exploring Expedition. (1845). North American Review, 61(1), 54, 106.

Viola, H. J., \& Margolies, C. (1985). Magnificent voyagers: The U.S. Exploring Expedition, 1838-1842 (pp. 15, 18, 20, 22, 37-39, 42, 44-45, 51, 54-55, 60-61, 63-65, 257-265). Washington, DC: Smithsonian Institution Press.

Weiss, S. C. (1999). The John C. Freemont 1842, 1843-'44 report and map. Journal of Government Information, 26(3), 297-313.

\section{Also Consulted}

American State Papers Naval Affairs No. 578. (1861). 26, 707-712.

Canal-Atlantic to Pacific. (1839). House Report 322, 25th Cong., 3rd Sess., 109, 111.

Cole, A.B. (1947a). The Ringgold Rodgers Brooke Expedition to Japan and the North-Pacific, 1853-1859. Pacific Historical Review, 16(2), 62.

Cole, A.B. (1947b). Yankee surveyors in the Shogun's Seas: Records of the United States surveying expedition to the North Pacific Ocean, 1853-1856. Princeton: Princeton University Press.

Kennedy, P.M. (1974). The Samoan Tangle: A study in Anglo-German-American relations, 1878-1900. New York: Barnes \& Noble Books.

Long, D.F. (1988). Gold braid and foreign relations: Diplomatic activities of U.S. Naval Officers (pp. 286-307). Annapolis: Naval Institute.

McDougall, W.A. (1993). Let the Sea Make A Noise: A History of the North Pacific from Magellan to 
MacArthur, . (pp. 286-307) New York: Basic Books.

Message of the President At the Commencement of the Session-Proclamation of Treaty With the Republic of Colombia of October 3, 1824. (1824). American State Papers Foreign Relations No. 412, 5:763-765.

Morison, S.E. (1961). American strategy in the Pacific Ocean. Oregon Historical Quarterly, 62(1), 5-56.

Narrative of the Expedition of an American Squadron to the China Seas and Japan Performed in the Years, 1852, 1853, and 1854 (1856). House Executive Document 97, 33rd Cong., 2nd Sess., Serials 802-804.

Proceedings of the American Philosophical Society, 109(3), 159-172.

Report of the secretary of the Navy. (1855). Senate Executive Document 1, 34th Cong., 1st Sess., 7-9.

Report of the secretary of the Navy. (1856). House Executive Document 1, 34th Cong., 3rd Sess., 408.

Report of the secretary of the Navy. (1860). Senate Executive Document 1, 36th Cong., 2nd Sess., 18: 44-48.

Schroeder, J. H. (1985). Shaping a maritime empire: The commercial and diplomatic role of the American Navy, 1829-1861 (pp. 5778, 139-164). Westport, CT: Greenwood Press.

U.S. Bureau of the Census. Historical statistics of the United States colonial times to 1970. Bicentennial edition, Vol. 2. (pp. 904-907) (1975). Washington, DC: GPO.

U.S. Department of the Interior. Office of Insular Affairs. A report on the state of the islands (pp. 10). Washington, DC: U.S. Department of the Interior.

Wiley, P.B., \& Ichiro, K. (1991). Yankees in the land of the gods: Commodore Perry and the opening of Japan. New York: Penguin Books.

Williams, F.W. (1963). Matthew Fontaine Maury: Scientist of the sea. New Brunswick: Rutgers University Press.

Bert Chapman is a government publications coordinator/associate professor of Library Science at Purdue University. His research interests include government publications on foreign policy and national security, as well as various topics in American and European History. 